\title{
PAX2 Gene
}

National Cancer Institute

\section{Source}

National Cancer Institute. PAX2 Gene. NCI Thesaurus. Code C73656.

This gene is involved in gene expression and cellular proliferation. 